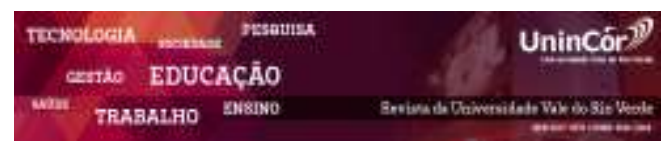

Revista da Universidade Vale do Rio Verde ISSN: 1517-0276 / EISSN: 2236-5362 v. 17 | n. 1 | Ano 2019

Carlos Henrique Levenhagen Universidade Vale do Rio Verde carloslevenhagen@gmail.com

Marcos Victor Levenhagen

Universidade Vale do Rio Verde mvlevenhagen@hotmail.com

Olívia da Cruz Campos

Universidade Vale do Rio Verde oliviacruz83@yahoo.com.br

Edson Camara de Drummond Alves Junior Universidade Vale do Rio Verde edsondrummondjr@hotmail.com

\section{TUTELAS PROCESSUAIS DE URGÊNCIA COMO INSTRUMENTO DE EFICÁCIA DA GARANTIA CONSTITUCIONAL DA RAZOÁVEL DURAÇÃO DO PROCESSO}

\begin{abstract}
The present work aims to explore the effectiveness of judicial protection within the Brazilian legal system, through the constitutional principles of duration and speed of proceedings, in order to structure the issues arising from it and to provide solutions to them, in the light of the urgency protectorship, by means of a bibliographical research.
\end{abstract}

Keywords: Reasonable duration of cases. Guardianship of urgency. Due process framework. Process celerity. Legal certainty

Recebido em: 27/10/2018 - Aprovado em: 31/03/2019 - Disponibilizado em: 15/07/2019

\section{INTRODUÇÃ̃O}

Tutela, pelo senso comum, tem como definição a proteção exercida em relação à alguém ou algo mais frágil; já a urgência, é explicitada nos dicionários como uma qualidade ou condição, uma necessidade que se requer solução imediata.

As tutelas já se encontravam em nosso ordenamento jurídico desde o Código Processo Civil de 1973 e se mantiveram presente no Novo Código de Processo Civil de 2015, e são 
instrumentos normativos importantes na pacificação social e também na eliminação de conflitos. São instrumentos de importância relevada que se fazem presentes no art. $5^{\circ}$, inciso XXXV da Constituição da República Federativa do Brasil de 1.988, que evocam o princípio da isonomia, já que promovem um reequilíbrio de forças, pois o ônus do tempo recai sobre aquele que provavelmente tem o direito, sendo mais comum o autor, entretanto, na tutela de urgência recairá sobre o réu, quando fundamentado o pedido autoral ao juiz.

Podemos distingui-las como tutela cautelar e conservativa, pois permite que o direito seja conservado/preservado; enquanto a tutela antecipada (que por sua vez é imediata) satisfaz, imediatamente, o direito pretendido.

As tutelas têm seus requisitos nos artigos 300 a 302 do Novo Código de Processo Civil no Capitulo I - Disposições Gerais, onde podemos citar o fumus boni iuris que consiste na probabilidade da existência do direito, onde se faz um juízo de probabilidade prévio e provisório; e o periculum in mora, que consiste no perigo de dano ou risco ao resultado útil do processo em virtude da sua demora.

Deste modo podemos observar a importância das tutelas de urgência neste mundo globalizado e instantâneo, além disto, é um instrumento jurídico afinado com a Constituição da República Federativa do Brasil de 1.988, através do Novo Código de Processo Civil.

O trabalho destaca a importância deste instrumento, sua aplicabilidade, no sentido de se buscar, com celeridade, a justiça, observando as partes envolvidas, se valendo de pesquisa uma bibliográfica e jurisprudencial para a sua devida elaboração.

Nos tópicos a seguir poderemos esmiuçar estas questões e constatarmos a importância deste instrumento jurídico.

\section{O ESTAdO E A SUA FUNÇÃO JURISDICIONAL}

A tutela jurídica do Estado possui conceito bastante amplo e de difícil elucidação. Segundo lição de Dinamarco (2.016), está relacionada às regras para a necessária coexistência em sociedade, em situações e valores considerados, visando à pacificação de pessoas e a eliminação de conflitos resultantes deste convívio social. Afirma, ainda, o mestre acima referido $(2.016$, p. 22$)$, que a:

Tutela jurisdicional às
pessoas, qualificada como
o amparo que, por obra
dos juízes, o Estado
oferece a quem tem razão
em uma causa posta em
juízo. Tutela é ajuda,
proteção.

A expressão "jurisdição", de acordo com o dicionário Aurélio (2.000, p. 323), significa: "poder atribuído a uma autoridade para fazer cumprir certas leis e punir quem as infrinja em determinada área”. Portanto, cumpre ao Estado, no exercício da função jurisdicional, solucionar e pacificar os conflitos pertinentes à vida em sociedade, possuindo como característica a inafastabilidade jurisdicional, conforme expressa a Constituição da República Federativa do Brasil de 1.988, em seu art.5 , XXXV, in verbis: "a lei não excluirá da apreciação do 
Poder Judiciário lesão ou ameaça a direito". Portanto, o Estado possui o poder de jurisdição, mas que somente será exercido, caso seja provocado.

Ao comentar acerca do exercício da jurisdição, assim se manifestou o mestre Dinamarco $(2.005$, p. 348), sobre a atuação dos juízes:

[...] o exercício da Jurisdição é feito pelo Estado mediante a atuação de agentes específicos, que são os juízes de todos os graus. Eles atuam como se fossem o próprio Estado, visto que este, como pessoa jurídica, constitui pura abstração sem existência física e não tem outro modo de externar seus desígnios e exercer seu poder senão por obra de pessoas físicas. Tais são os juízes, que corporificam o Estado e o representam no exercício da jurisdição.

Assim, a tutela jurisdicional diz respeito a um exercício realizado pelo Estado em favor do titular de um direito subjetivo, de acordo com a norma jurídica, no caso em concreto, de forma que o Judiciário, por meio de seus agentes investidos (juízes) e Tribunais, possa apreciar a causa e julgar, eliminando o conflito de interesses, levando à paz social e promovendo o desenvolvimento econômico da sociedade.

\section{TUTELA DE URGÊNCIA}

Com a finalidade de efetivar o artigo $5^{\circ}$, inciso LXXVIII da Constituição da República Federativa do Brasil de 1.988, que trouxe a duração razoável do processo e sua celeridade, a
Lei Federal 13.105/2015 advém em nosso sistema legal para trazer-nos um novo sistema processual civil, com mecanismos passíveis de se evitar prejuízos ou riscos que a longa duração do processo possa resultar para uma das partes. O referido diploma processual trouxe inúmeras inovações, sendo uma das que mais chama a atenção é a denominada "Da Tutela Provisória", prevista nos artigos 294 a 311 do Novo Código de Processo Civil, provimento jurisdicional não definitivo, dividida em tutelas provisórias de urgência (antecipada e cautelar) e de evidência, que no entendimento de Humberto Theodoro Junior (2.016, p. 610):

As tutelas provisórias têm
em comum a meta de
combater os riscos de
injustiça ou de dano,
derivados da espera,
sempre longa, pelo desate
final do conflito
submetido à solução
judicial.

A tutela de urgência, sendo uma das tutelas diferenciadas, tem como objetivo, assim, combater o perigo de dano que a longa duração processual pode criar para o respectivo titular da ação, resguardando o resultado do processo e proporcionando ao jurisdicionado uma prestação jurisdicional efetiva, conforme expressa Mesquita (2.002, p.174):

[...] não pode a demora jurisdicional ser imputada ao jurisdicionado, que não lhe rendera ensejo e, portanto, tem direito a uma tutela tempestiva e adequada, devendo ser eliminado qualquer desvio que possa comprometer o gozo integral do bem da vida que lhe é próprio. $\mathrm{O}$ 


\begin{abstract}
monopólio estatal da jurisdição impõe uma atitude tendente a coibir qualquer dano que porventura venha a ser causado pelo próprio Estado. Várias são as razões que conspiram contra a celeridade a requererem medidas garantidoras de que a tutela será devidamente útil no futuro.
\end{abstract}

As tutelas de urgência baseiam-se nos requisitos do fumus boni iuris ${ }^{1}$ e do periculum in $m o r a^{2}$. Assim, para que seja satisfeita a tutela de urgência, a parte deverá demonstrar justo temor de que, enquanto aguarda a tutela definitiva, existe o risco de perecimento, ou perigo de dano sobre o objeto do litígio, além da probabilidade do direito material invocado por quem pretenda segurança.

Nesse sentido podemos citar uma decisão recente do Tribunal de Justiça do Estado do Rio Grande do Sul (TJRS):

AGRAVO DE INSTRUMENTO ESTATUTO

\footnotetext{
${ }^{1}$ De acordo com a lição de Marinoni (2.016, p. 382): “[...] é a probabilidade lógica - que é aquela que surge da confrontação das alegações e das provas com os elementos disponíveis nos autos, sendo provável a hipótese que encontra maior grau de confirmação e menor grau de refutação nesses elementos. $O$ juiz tem que se convencer de que o direito é provável para conceder tutela provisória".

2 Ainda, segundo sábias palavras do professor Luiz Guilherme Marinoni (2.016, p. 209): "O perigo na demora é suficientemente certo, ademais, para viabilizar tanto uma tutela contra o ilícito como uma tutela contra o dano. Há perigo na demora porque, se a tutela tardar, o ilícito pode ocorrer, continuar ocorrendo, ocorrer novamente, ou pode o dano ser irreparável, de difícil reparação ou não encontrar adequado ressarcimento. Daí que 'perigo de dano' e 'risco a resultado útil do processo' devem ser lidos como 'perigo na demora' para caracterização da urgência - essa leitura permitirá uma adequada compreensão da técnica processual à luz da tutela dos direitos".
}

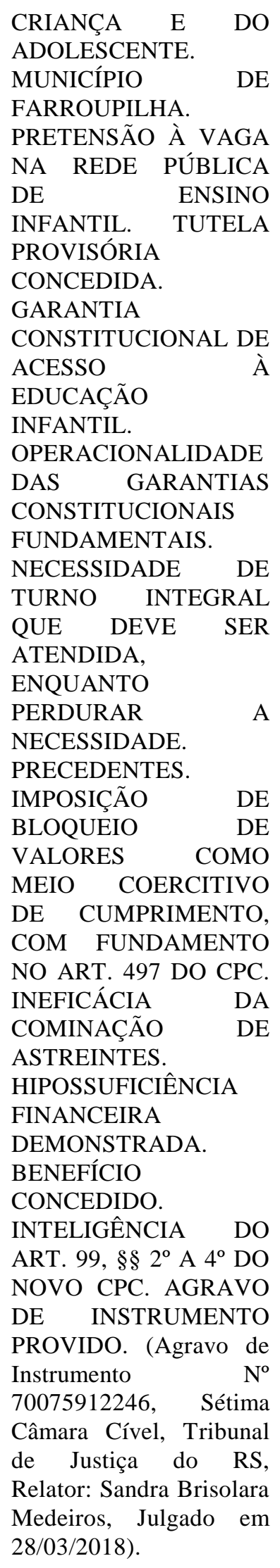




\section{TUTELA DE URGÊNCIA CAUTELAR E} ANTECIPADA

As formas de tutelas de urgência são definidas em cautelar e antecipada, sendo, portanto, os meios pelos quais o processo irá resguardar o objeto da lide e antecipar seu objetivo final, perante um eventual dano, uma resposta à demora processual, o que, para a sua obtenção, necessário o preenchimento dos requisitos legais, além de verificar a oportunidade e possibilidade de permissão dentro do processo.

De acordo com o ensinamento de Humberto Theodoro Junior (2.016, p. 623):

Os requisitos, portanto, para alcançar-se uma providência de urgência de natureza cautelar ou satisfativa são basicamente dois: (a) um dano potencial, um risco que corre o processo de não ser útil ao interesse demonstrado pela parte, em razão do periculum in mora, risco esse que deve ser objetivamente apurável. (b) A probabilidade do direito substancial invocado por quem pretenda segurança, ou seja, o fumus boni iuris.

Muito se discute a respeito das diferenças e conceituações entre as tutelas cautelar e antecipada, pois constituem espécies do gênero tutela provisórias de urgência, além de possuírem requisitos idênticos, como a forma em que serão concedidas incidentalmente ou exteriormente dentro do processo, buscando afastar uma situação de perigo. Seguindo os ensinamentos de Humberto Theodoro Junior (2.016, p. 623):
[...] continua, porém, relevante a distinção entre tutela cautelar (conservativa) e a tutela antecipatória (satisfativa), porque (i) a medida cautelar tem a sua subsistência sempre dependente do procedimento que, afinal, deverá compor o litígio que se pode dizer "principal", ou "de mérito"; enquanto (ii) a tutela antecipada pode, por conveniência das partes, estabilizar-se, dispensando o prosseguimento do procedimento para alcançar a sentença final de mérito, e, portanto, sem chegar à formação da coisa julgada.

Portanto, na antecipada, satisfaz-se o próprio direito material, ou seja, o juiz permite que a parte goze de efeitos da tutela definitiva de forma antecipada, enquanto na cautelar, protege-se o direito pleiteado para depois se satisfazer com o mesmo, assim, o juiz profere uma medida provisória para salvaguardar o próprio direito que será gozado ao final.

\subsection{Tutela de urgência cautelar}

A tutela cautelar trata-se de uma medida que possui o objetivo de assegurar a satisfação do processo principal, possibilitando a eficácia do resultado, evitando que o mesmo se torne desnecessário com a demora do processo. Assim, a tutela cautelar pode ser definida como uma tutela não satisfativa com efeitos antecipáveis, tendo como objetivo, portanto, preservar os efeitos principais da tutela que a demora processual possa ocasionar.

Conforme ensinamento do doutrinador Humberto Theodoro Júnior (2.016, p. 652): 
A sua finalidade é conservar bens, pessoas ou provas, que possam sofrer alguma lesão ou perigo de lesão em razão da longa duração da marcha processual. Assim, antes mesmo de ajuizada a ação contendo o pedido principal, a parte poderá requerer, de forma antecedente, a proteção provisória de seu direito.

O pedido da tutela conservativa (cautelar) pode ser requerida em caráter antecedente/preparatória ${ }^{3}$ (realizada antes do ajuizamento do pedido principal) ou incidental (realizada durante o trâmite do pedido principal), tendo em ambos os casos os requisitos do fumus boni iuris e de periculum in mora.

Em caso de pedido de tutela de urgência cautelar antecedente, regulada nos arts. 305 a 310 do Novo Código de Processo Civil, deverá dizer-se qual será o pedido principal, indicando a lide e seu fundamento, a exposição do direito que se objetiva assegurar e o perigo de dano ou o risco ao resultado útil do processo. A exposição sumária do direito, prevista no art. 305 do Estatuto Processual Civil brasileiro, nada mais é do que a forma de destacar-se o interesse processual, representado pelo direito de ação, com um mínimo de viabilidade, demonstrando o fumus boni iuris e o periculum in mora.

3 Considera-se antecedente toda medida urgente pleiteada antes da dedução em juízo do pedido principal, seja ela cautelar ou satisfativa. Em regra, ambas são programadas para dar seguimento a uma pretensão principal a ser aperfeiçoada nos próprios autos em que o provimento antecedente se consumou (THEODORO, 2.016, pg. 650).
Assim, Paulo Junior Trindade dos Santos (2.015, p. 248) define que a tutela de urgência cautelar antecipada visa:

assegurar a eficácia da decisão final do processo principal, mas nunca tem o mesmo conteúdo do acolhimento do pedido principal, porque não se destina a antecipá-lo, mas a assegurar a eficácia.

As medidas cautelares, de modo que continuam sendo medidas destinadas a garantir o resultado útil e eficaz do processo, necessitam que seja demonstrado o interesse do autor envolvido na lide. É o que se conclui das palavras de Assumpção Neves (2.016, p. 966):

A natureza jurídica,
entretanto, não pode ser
definida pela vontade do
legislador, restando
inalterada a distinção
entre a tutela cautelar
como garantidora do
resultado útil e eficaz do
processo e a tutela
antecipada como
satisfativa do direito da
parte no plano fático.

Para sua concessão, a parte deverá apresentar no prazo de 30 (trinta dias), uma peça complementar, após a efetividade da tutela cautelar antecedente, caso contrário perderá seu efeito, em outras palavras, terá a sua eficácia interrompida, e desta forma a parte interessada ficará impedida de requerê-la novamente, conforme evidencia o parágrafo único do artigo 309 do atual Código de Processo Civil. Lado outro, a sentença que julga improcedente o pedido de tutela cautelar antecedente não prejudicará que a parte formule o pedido principal, e nem no julgamento deste, salvo se o motivo do indeferi- 
mento for o reconhecimento de decadência ou de prescrição, conforme preceitua o artigo 310 do Código de Processo Civil.

Já tutela provisória de urgência de natureza cautelar incidental, é aquela pleiteada no curso do processo ou na inicial, junto com o pedido principal e efetivada através de diversas formas, conforme prevê o artigo 301 do Código de Processo Civil, in verbis: "A tutela de urgência de natureza cautelar pode ser efetivada mediante arresto, sequestro, arrolamento de bens, registro de protesto contra alienação de bem e qualquer outra medida idônea para asseguração do direito." Nesta modalidade de tutela provisória de urgência de natureza cautelar incidental não se busca a antecipação do mérito, sendo pretendido tão-somente conservar o direito da parte requerente.

\subsection{Tutela de urgência antecipada}

A tutela antecipada (satisfativa) pode ser requerida em caráter antecedente ou incidental, e nada mais é do que uma antecipação do mérito, para evitar ou fazer cessar o perigo de dano, revelando-se apropriada em casos, nos quais, presente uma situação de perigo iminente para o próprio direito. Garantindo, portanto, um adiantamento dos efeitos que o provimento final lhe garantiria, e que conforme preceitua Humberto Theodoro Junior (2.016, p. 661):

A tutela satisfativa tem utilidade em casos de ameaça não à utilidade do processo, mas ao próprio direito subjetivo material da parte, que não se acha em condições de aguardar o desfecho natural do processo ordinário.
$\mathrm{Na}$ hipótese de requerimento da tutela antecipada incidental, a mesma será proposta no curso do processo, caso o autor entenda que existam condições para a concessão de tutela antecipada a seu favor, fazendo pedido expresso nesse sentido. Lado outro, o Código de Processo Civil, em seus arts. 303 e 304, admite a tutela antecipada requerida em caráter antecedente, na qual o autor poderá ingressar com o pedido de tutela provisória satisfativa antes da propositura da ação. O art. 303 do referido Estatuto estipula que:

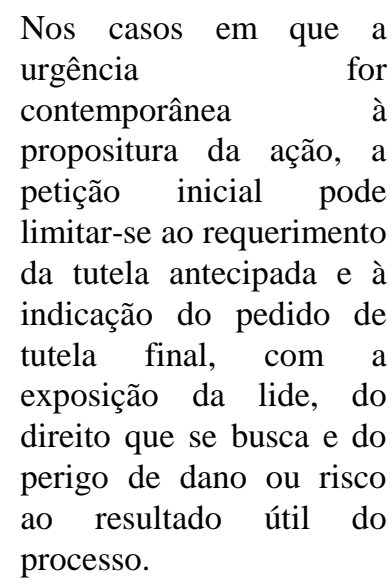

Sendo assim, a tutela antecipada antecedente assegura a aplicabilidade do direito material, devendo o autor demonstrar perante juízo que, além da urgência, o direito material está em risco, se não for concedida a medida e conforme reza o artigo 303, $\S 1^{\circ}$, I do Código de Processo Civil, após aprovado o pedido de tutela antecipada antecedente, deverá aditar a petição inicial com documentos, a complementação de seus fatos alegados e o pedido da tutela final, devendo respeitar o prazo de 15 dias ou outro fixado pelo magistrado.

Ponto em destaque é que deferida a tutela antecipada antecedente e, intimado o réu, a medida provisória se estabilizará, caso não haja recurso da sua concessão, mesmo após a 
extinção do processo, o que só poderá ser modificada em futura ação, ajuizada no prazo de 02 (dois) anos. Nesse sentido, o doutrinador Marcus Vinicius Rios Gonçalves (2.016, p. 380) afirma que:

A tutela antecipada antecedente não adquire, ao menos nos dois anos iniciais, caráter de definitividade, e não se reveste da autoridade da coisa julgada material, mas adquire estabilidade, o que significa que o juiz não poderá mais revogá-la ou fazer cessar-lhe a eficácia livremente. Para tanto, será necessário que as partes ajam na conformidade do art. 304, $\S 2^{\circ}$, do CPC, dentro do prazo de dois anos.

A respeito da estabilização da tutela antecedente, ensina também Luiz Guilherme Marinoni (2.016, p. 227): infraconstitucional incumbido de densificá-lo.

\section{EMENDA CONSTITUCIONAL 45/2004}

A Emenda Constitucional número 45, de 08 de abril de 2.004, trouxe inúmeras inovações à Constituição da República Federativa do Brasil de 1.988, entre todas as inovações a mais importante foi a do inciso LXXVIII no art. $5^{\circ}$ da Lei Maior, in verbis:

A todos, no âmbito judicial e administrativo, são assegurados a razoável duração do processo e os meios que garantam a celeridade de sua tramitação.

A incorporação de uma garantia constitucional para resguardar a dignidade da pessoa humana, fundada na razoável duração do processo, foi um grande marco para o crescimento .... a estabilização da tutela antecipada antecedente não pode lograr a autoridade da coisa julgada que é peculiar aos procedimentos de cognição exauriente. Passado o prazo de dois anos, continua sendo possível o exaurimento da cognição até que os prazos previstos no direito material para a estabilização das situações jurídicas atuem sobre a esfera jurídica das partes (por exemplo, a prescrição, a decadência e a suspensão). Em resumo: o direito à adequada cognição da lide constitui corolário do direito ao processo justo e determina a inafastabilidade da ação exauriente para formação da coisa julgada. Fora daí há ofensa ao direito fundamental ao processo justo pelo próprio legislador da aplicabilidade da tutela jurisdicional do Estado. Nesse sentido, a decisão do Supremo Tribunal Federal acerca do assunto firma que:

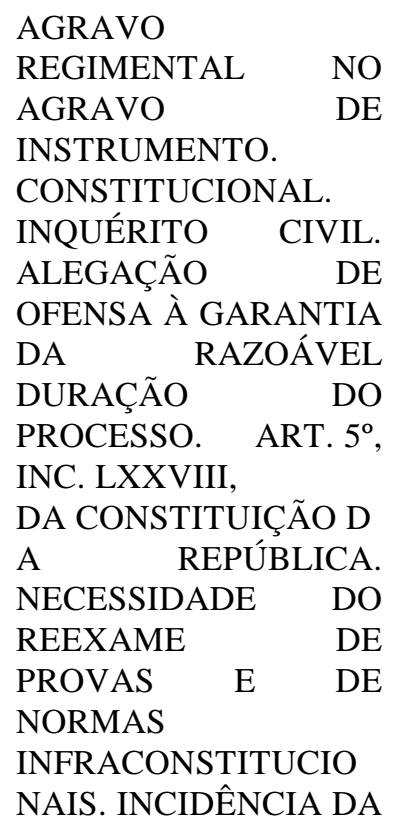


SÚMULA N. 279 DO

SUPREMO TRIBUNAL

FEDERAL. OFENSA

CONSTITUCIONAL

INDIRETA. AGRAVO

REGIMENTAL AO

QUAL SE NEGA

PROVIMENTO.

CONSTITUCIONAL E

ADMINISTRATIVO.

LICENÇA

AMBIENTAL.

DEMORA

NA

CONCESSÃO.

RAZOÁVEL

DURAÇÃO

PROCESSO. MATÉRIA

INFRACONSTITUCIO

NAL.

ART. $5^{\circ}$, LIV, LV e LXX

VIII,

DA CONSTITUIÇÃO

FEDERAL. OFENSA

REFLEXA. 1. A juris-

prudência do Supremo

Tribunal Federal é pací-

fica em não admitir recurso extraordinário para debater matéria referente à ofensa aos postulados constitucionais da ampla defesa, do contraditório, do devido processo legal e da prestação jurisdicional, pois, se existente, seria meramente reflexa ou indireta. 2. Contrariedade aos

arts. $5^{\circ}$, LIV, LV, LXXV

III, da Constituição Federal, que não prescinde da análise de legislação infraconstitucional (Lei Municipal 8.896/2002) e do corpo probatório dos autos. Incidência das Súmulas STF 279 e 280.

3 . Em sede de recurso extraordinário não é permitido inovar com argumentos não abordados pelo acórdão recorrido, nem pelos embargos de declaração opostos. Ausência do necessário prequestionamento (Súmula STF 282). 4. Agravo regimental improvido. AGRAVO

REGIMENTAL EM RECURSO
EXTRAORDINÁRIO.

REQUERIMENTO

ADMINISTRATIVO.

GARANTIA DA

DURAÇÃO

RAZOÁVEL DO

PROCESSO (INCISO

LXXVIII DO ART. 5

DO MAGNO TEXTO). CONTROVÉRSIA

DECIDIDA

EXCLUSIVAMENTE À

LUZ DO CONJUNTO

FÁTICO-PROBATÓRIO DOS AUTOS.

INCIDÊNCIA DA

SÚMULA 279/STF. 1.

Caso em que entendimento diverso do adotado pelo Tribunal de Justiça do Estado do Rio Grande do Norte demandaria a análise dos fatos e provas constantes dos autos. Providência vedada na instância recursal extraordinária. 2. Agravo regimental desprovido. Nesse sentir, não merece processamento o apelo extremo, consoante também se denota dos fundamentos da decisão que desafiou o recurso, aos quais me reporto e cuja detida análise conduz à conclusão pela ausência de ofensa direta e literal a preceito da Constituição da República. Conheço do agravo para negar-lhe provimento (art. 544, § $4^{\circ}$, II, "a", do CPC). (STF - ARE: 715760 RJ, Relator: Min. ROSA WEBER, Data de Julgamento: 14/11/2012, Data de Publicação: DJe-232 DIVULG 26/11/2012 PUBLIC 27/11/2012).

A contribuição da Emenda Constitucional, com a implementação do princípio da razoável duração do processo como direito de dignidade humana, foi de suma importância para os processos, pois, a partir deste princípio, a Constituição da República Federativa do Brasil 
de 1.988 passou a adotar uma postura com viés processual, delimitando as regras da tramitação dos processos, a fim de acelerar a prestação jurisdicional.

Dinamarco (2.005, p. 44) assim descreve sobre a Emenda Constitucional 45/2.004:

Os reformadores estiveram conscientes de que a maior debilidade do Poder Judiciário brasileiro em sua realidade atual reside e sua inaptidão a oferecer uma justiça em tempo razoável, sendo sumamente injusta e antidemocrática a outorga de decisões tardas, depois de angustiosas esperas e quando, em muitos casos, sua utilidade já se encontra reduzida ou mesmo neutralizada por inteiro. De nada tem valido a Convenção Americana de Direitos Humanos, em vigor neste país desde 1978, incorporada que foi à ordem jurídica brasileira em 1992 (Dec. 678, de 6.11.92); e foi talvez por isso que agora

a Constituição quis, ela própria, reiterar essa promessa mal cumprida, fazendo-o em primeiro lugar ao estabelecer que "a todos no âmbito judicial e administrativo, são assegurados a razoável duração do processo e os meios que garantam a celeridade de sua tramitação (art. $5^{\circ}, \quad$ inc. LXXVIII, red. EC n. 45, de 8.12.04).

A inserção do princípio do direito à razoável duração do processo induz a preocupação do legislador com a efetividade do processo como meio de realização da justiça. Logo, tal direito visa não somente adequar o processo, mas também efetivar os direitos e garantias fundamentais à dignidade da pessoa humana.

\section{PRINCÍPIO CONSTITUICIONAL DO ACESSO À JURISDIÇÃO}

A Constituição da República Federativa do Brasil de 1.988 confere o acesso à justiça, ao trazer, expressamente, em seu artigo $5^{\circ}$, inciso XXXV, in verbis: "a lei não excluirá da apreciação do Poder Judiciário lesão ou ameaça a direito". O Estado traz para si a responsabilidade de resolver os conflitos sociais, disponibilizando a tutela jurisdicional àqueles que dela necessitar, apresentando uma decisão a respeito da ameaça ao direito tutelado. Esse princípio é de tamanha relevância que podemos levá-lo a status de direitos humanos, pois se protege, da pessoa, o direito de buscar na tutela jurisdicional a proteção diante de lesão ou ameaça a seu direito.

Como exemplo de facilitação do Estado ao acesso à justiça, o novo Código de Processo Civil, em seu art. 98, garante que todo aquele que não tem condições financeiras, poderá requerer os benefícios da Justiça Gratuita, ficando isentos das despesas financeiras no decorrer de um processo.

Além disso, para que o processo seja efetivo, não basta que seja garantido o acesso à justiça, as decisões devem ser práticas e essenciais para a vida do indivíduo. Nesse sentido, Freddie Didier e outros (2.009, p. 67) trazem o conceito de jurisdição, nos seguintes termos:

A jurisdição é a função atribuída a terceiro imparcial (a) de realizar o 


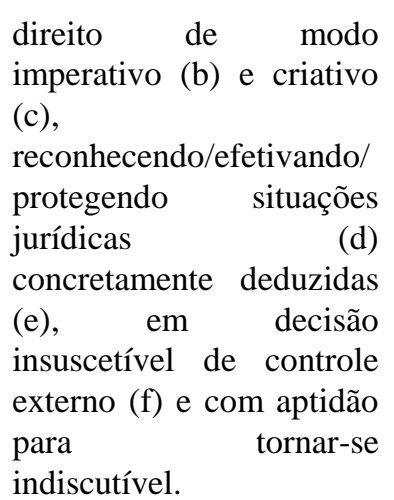

Para que a relação processual tenha validade é necessária a imparcialidade do magistrado. Em nosso ordenamento jurídico essa função é desempenhada pelo Poder Judiciário, que é o responsável pela solução dos conflitos de interesses quando provocado. $\mathrm{O}$ terceiro imparcial, representado pelo juiz, deverá decidir o caso, e dizer às partes, qual delas possui o direito. Embora o Estado sirva para proteger o indivíduo, ele é inerte, exercendo, portanto, a jurisdição quando provocada. É por isso que a imparcialidade é vista como pressuposto necessário à atividade jurisdicional.

Com base nessa ótica, o Direito Processual Civil vem buscando um melhor aperfeiçoamento do processo para atender de forma justa, eficiente, e satisfatória, os interesses pretendidos.

Diversos são os recursos, utilizados pelo Código de Processo Civil, a fim de facilitar o acesso à justiça a todos, eliminando as barreiras que dificultam o bom andamento processual. Estimula, para isso, a auto-composição, mediação e conciliação, defende o diálogo entre o julgador e as partes, garante o dever da fundamentação das decisões pelo juiz, passa a permitir a prática de atos processuais, o depoimento pessoal (inclusive por vídeoconferência), a sustentação oral, a acareação e a oitiva de testemunha. Outro grande avanço que busca facilitar o acesso à justiça, privilegia as tutelas de urgência, de modo que afasta o perigo da demora até que seja concedida a tutela definitiva. Esses são apenas alguns exemplos que demonstram a busca pela simplificação do acesso à justiça pelo Novo Código de Processo Civil (lei 13.105/2.015).

\section{DEVIDO PROCESSO LEGAL E A RAZOÁVEL DURAÇÃO DO PROCESSO}

O princípio do devido processo legal ou princípio da legalidade está previsto na Constituição da República Federativa do Brasil de 1.988 , em seu art.5 $5^{\circ}$ inciso LIV, in verbis: "Ninguém será privado da liberdade de seus bens sem o devido processo legal”. Tal princípio garante ao titular a proteção de seus bens, afastando o poder arbitrário do Estado, e assegurando a cada um o que é seu por direito, através de um processo justo. Podemos perceber que o princípio da legalidade não é só uma proteção individual, mas uma garantia constitucional que protege o particular de sanções a ele imposta que não esteja garantida por lei, sendo que "Trata-se de conquista que remonta ao século XIII, com a edição da Magna Carta, por João Sem Terra" (GONÇALVES, 2.017, p.61). A partir desse princípio, surgem todos os demais.

Outro princípio de grande relevância para o Processo Civil está previsto no art. $5^{\circ}$, inciso LXXVIII, que define: "A todos no âmbito judicial e administrativo, são assegurados a razoável duração do processo e os meios que 
garantem a celeridade de sua tramitação". O Novo CPC reafirma tal dispositivo em seu art. $4^{\circ}$ ao preceituar que as partes envolvidas no processo, possuem o direito de obter, em prazo razoável, a solução do litígio. Podemos verificar a preocupação do legislador com a demora da justiça no julgamento dos processos e as diversas medidas objetivando a busca de uma solução mais ágil aos litígios, como exemplo, podemos citar a amplificação dos casos em que são cabíveis as tutelas de urgência, o processo eletrônico, a redução da quantidade de recursos, súmulas vinculantes, dentre vários outros meios que vem contribuindo para que o processo tenha uma solução rápida.

Nesse sentido, NEVES (2.016, p. 55-56), afirma que:

O processo deve ter uma duração razoável, sob pena de se tornar inócua uma decisão tardia. [...]. Nessa busca, não pode haver a aceleração dos procedimentos, diminuindo-se as garantias processuais constitucionais [...]. Mais importante que ser ágil é ser, o processo, efetivo, eficaz, dizendo os direitos das partes em tempo que, não devendo ser longo, não poder ser açodado. [...]. Assim, conclui-se que o direito ao processo com duração razoável é impostergável, tendo em vista o Estado Democrático de Direito, e deve ser valorado à luz de vários critérios. Respaldados na jurisprudência firmada pelo Tribunal Europeu de Direitos Humanos, diversos doutrinadores ensinam que devem ser levados em consideração três critérios principais com o objetivo de analisar o caráter razoável da duração razoável do processo, quais sejam, a complexidade das questões, de fato e de direito, presentes no processo, $\quad 0$ comportamento das partes e seus procuradores, e a atuação dos órgãos jurisdicionais em cada caso concreto.

A duração razoável do processo faz com que a própria tutela jurisdicional ocorra em tempo hábil, garanta uma economia processual e dê uma resposta célere e efetiva aos envolvidos na lide.

\section{PRAZO NO PROCESSO CIVIL}

A delonga na prestação jurisdicional no ordenamento jurídico brasileiro tem ocasionado inúmeras discussões no decorrer do tempo, pois as demandas processuais existentes perdem sua eficácia ao longo dos anos, tornando-se cada vez mais difícil a obtenção de uma tutela satisfativa. Tal situação, conforme abordado no trabalho, fere o princípio substancializado no artigo $5^{\circ}$, LXXVIII da Constituição da República Federativa do Brasil de 1.988, introduzido pela Emenda Constitucional $\mathrm{n}^{\circ}$ 45/2.004, que assegura a todos, no âmbito judicial e administrativo, a razoável duração processual e os meios que assegurem a celeridade de sua tramitação.

O Direito dispõe de instrumentos legais que tendem afastar as incertezas, o que não se difere no âmbito processual civil, em que há o desejo de um processo justo. Nesse sentido, visando minorar o excesso de demandas judiciais, faz com que o legislador proporcione 
constantes mudanças legislativas, a fim de ter uma justiça célere e eficaz.

O novo Código de Processo Civil, em seu artigo $04^{\circ}$, prevê o princípio da duração razoável do processo, estipulando que: "As partes têm o direito de obter em prazo razoável a solução integral do mérito, incluída a atividade satisfativa". Assim, a lei nacional 13.105/2.015 veio reforçar a ideia de preocupação com a tempestividade do processo, para que não tenhamos um processo eterno, mas sim em um tempo razoável para que as partes possam assegurar a pretensão em vida, a quem tem direito.

Assim se manifestou Humberto Theodoro (2.016, p. 65):

É evidente que sem
efetividade, no
concernente ao resultado
processual cotejado com
o direito material
ofendido, não se pode
pensar em processo justo.
Não sendo rápida a
resposta do juízo para a
pacificação do litígio, a
tutela não se revela.
Ainda que afinal se
reconheça e proteja o
direito violado, o longo
tempo em que o titular, no
aguardo do provimento
judicial, permaneceu
privado de seu bem
jurídico, sem razão
plausível, somente pode
ser visto como uma
grande injustiça.

Ademais, o Código de Processo Civil, em seu artigo $06^{\circ}$, determina que: "Todos os sujeitos do processo devem cooperar entre si para que se obtenha, em tempo razoável, decisão de mérito justa e efetiva". Portanto, o objeto a ser alcançado pela lei nacional 13.105/2.015 é a garantia que o pedido será analisado em tempo razoável, mediante decisão de mérito através de uma tutela jurisdicional, com utilização do princípio da cooperação, boa-fé das partes. Theodoro (2.016, p. 65) continua:

A fiel aplicação da garantia constitucional em apreço exige das partes um comportamento leal e correto, e, do juiz, uma diligência atenta aos desígnios da ordem institucional, para não se perder em questiúnculas formais secundárias $\mathrm{e}$, sobretudo, para impedir e reprimir, prontamente, toda tentativa de conduta temerária dos litigantes.

Podem influenciar, na duração razoável do processo, diversos fatores como a natureza e a complexidade da causa, o comportamento das partes e das autoridades judiciárias e a necessidade de se respeitar prazos para atos processuais necessários. Porém, para que o processo se submeta aos ditames da duração razoável previstos na Lei Maior de 1.988 e no Código de Processo Civil, se exige que seja conduzido o mesmo de maneira a respeitar as regras procedimentais previstas em leis.

\section{APLICABILIDADE DAS TUTELAS DE URGÊNCIA NO ORDENAMENTO JURIDICO ATUAL}

As tutelas de urgência são mecanismos utilizados pelos operadores do Direito para antecipar o processo e obter a tutela jurisdicional pretendida já no início do processo. Portanto, visa à efetividade da tutela jurisdicional, de maneira célere, como modo de obter justiça.

Dessa forma, o Estado, ao se preocupar com a efetividade da jurisdição, criou meca- 
nismos para sua aplicabilidade na prestação da justiça que, no Novo Código de Processo Civil, $\operatorname{logo}$ no art. $4^{\circ}$, tratou de repetir o princípio da razoável duração do processo. Não se trata de uma mera redundância jurídica, mas uma forma de intensificar, dar concretude ao princípio constitucional trazido pelo constituinte derivado.

Assim, o Estado, com o objetivo de cumprir com o princípio da razoável duração processual, deve, perante o caso concreto levado ao Judiciário, verificar e impor a tutela jurisdicional a fim de efetivar o direito material posto em questão sob sua efigie.

Nesse sentido a doutrina de Luiz Guilherme Marinoni (2.009, p. 114) explica que:

A concretização da norma processual deve tomar em conta as necessidades de direito material reveladas no caso, mas a sua instituição decorre, evidentemente, do direito fundamental à tutela jurisdicional efetiva. O legislador atua porque é ciente de que a jurisdição não pode dar conta das variadas situações concretas sem a outorga de maior poder e mobilidade, ficando o autor incumbido da identificação das necessidades concretas para modelar a ação processual, e o juiz investido do poder-dever de, mediante argumentação própria e expressa na fundamentação da sua decisão, individualizar a técnica processual capaz de lhe permitir a efetiva tutela do direito.

Entende-se que o Estado, após inserir a razoável duração do processo no rol dos direitos e garantias fundamentais, dando maior con- cretização ao preceito fundamental de acesso à jurisdição, previsto no art. $5^{\circ}$, XXXV, da Constituição da República Federativa do Brasil de 1.988, incumbiu-se do dever de proporcionar meios (tutelas provisórias) capazes de proporcionar uma redução da longa demora jurisdicional.

Logo, houve um fortalecimento das tutelas no ordenamento jurídico processual brasileiro, pois, as tutelas provisórias tornaram-se instrumentos que buscam evitar o perecimento do direito em decorrência do tempo, constituindo uma forma que o Estado visa amenizar o ônus ocasionado pela demora processual, bem como distribuí-los entre as partes no processo.

A tutela de urgência surge como meio de demonstração do direito que se dá em momento anterior a sentença, deixando a parte no direito de gozo da tutela jurisdicional do Estado antes do exaurimento do Juiz, surgindo a efetividade jurisdicional. Nesse diapasão, o legislador facilita os requisitos para a concessão da tutela de urgência satisfativa e cautelar, devendo o autor demonstrar ao Estado a probabilidade do direito conjugado com o perigo de dano ou risco ao resultado útil processual. Assim preceitua Damasceno Penati (2.015, pag. 147):

(...) verifica-se que, como ressaltado alhures no que diz respeito à busca de efetividade da prestação da tutela jurisdicional, o legislador "facilitou" a concessão da tutela antecipada, ao vindicar tão somente a caracterização do requisito da "aparência do direito", dependendo, dessa forma, do entendimento do magistrado no caso concreto, em uma notável discricionariedade conferida 
pelo NCPC. (...) Dessa feita, revela-se claro o intuito do legislador de garantir efetividade ao acesso ao Poder Judiciário, tendo em vista a criação e a consequente evolução do aludido provimento hábil a desembargar os prejuízos resultantes da duração do imaculado princípio do due process of law, com todas as regras e garantias fundamentais de procedimento, os quais, sem sombra de dúvidas, ocasionam prejuízos irreversíveis, caso sejam seguidos à risca pelo magistrado, isto é, sem o sopesamento de direitos por parte do juiz e sem as ferramentas previstas das tutelas provisórias.

Busca-se, portanto, demonstrar que os pedidos de tutela de urgência exigem que, ao julgar, o juiz realize um processo de ponderação favorável ao bem jurídico tutelado, que, se, por outro lado, for aguardar o trâmite regular do processo, certamente o objeto irá perecer. Assim, na visão de Humberto Theodoro Jr. (2.007, p. 734), se afirma que o processo:

[...] deve amoldar-se aos desígnios do direito material, de sorte a não simplesmente assegurar a composição do litígio e a reparação do dano que o titular do direito lesado suportou, mas a proporcionar a melhor e mais rápida e objetiva concretização do direito da parte que tem razão. O processo deve estar voltado para a efetividade, evitando, quando possível, o dano ou o agravamento do dano ao direito subjetivo. [...] Múltiplos são os expedientes de que o direito processual se vale na luta em prol da efetividade do processo e na coibição dos efeitos do tempo sobre os resultados do processo [...] Com todos esses caminhos especiais se intenta proporcionar as chamadas tutelas diferenciadas, que, além da sumarização dos procedimentos comuns, conduzem também àquilo que configura as modernas tutelas de urgência, de que o direito processual atual não pode prescindir para realizar o anseio de efetividade.

Destarte, nosso ordenamento jurídico estipula medidas de tutelas de urgência diferenciadas, aplicadas a cada caso concreto, na qual irão atenuar algumas garantias processuais, é certo que objetivam algo mais do que a antecipação do direito, pois destinam-se, além de tudo, a assegurar a presteza do processo em discordância com o tempo, bem como conceder o acesso a uma ordem jurídica justa, sendo, portanto, um legítimo meio processual propenso a afagar tais mazelas e a injustiça.

Teresa Arruda Alvim Wambier (2.016, p. 540) apontou as seguintes considerações sobre as tutelas:

[...] A tutela cautelar e a tutela antecipada, na terminologia usada pelo NCPC, são espécies do mesmo gênero (tutela de urgência) com muitos aspectos similares. Ambas estão caracterizadas por uma cognição sumária, são revogáveis e provisórias e estão precipuamente vocacionadas a neutralizar os males do tempo no processo 
judicial, mesmo que por meio de técnicas distintas, uma preservando (cautelar) e outra satisfazendo (antecipada). Em outras palavras, a tutela cautelar evita que o processo trilhe um caminho insatisfatório que o conduzirá à inutilidade. Por sua vez, a tutela antecipada possibilita à parte, desde já, a fruição de algo que muito provavelmente virá a ter reconhecido a final. Pode-se dizer que na cautelar protege-se para satisfazer, enquanto na tutela antecipada satisfaz-se para proteger. Cada uma a seu modo, ambas têm a mesma finalidade remota, ou seja, estão vocacionadas a neutralizar os males corrosivos do tempo no processo.

Assim, as tutelas de urgência antecipadas e cautelares contribuem de maneira substancial aos interesses do jurisdicionando na busca da tutela do Estado, realizando o que está proposto pela Lei Maior de 1.988, no papel de garantidor de direitos fundamentais.

\section{CONSIDERAÇÕES FINAIS}

Os institutos das tutelas da urgência, cautelares e antecipadas, são aplicados em casos concretos mediante análise de exigências e pressupostos de aplicação de sua concessão, e têm por finalidade abreviar o longo decurso de tempo entre a inserção da ação e a existência real do direito pleiteado pela parte. Destaca-se que a capacidade de tais medidas de alcançar a finalidade do chamado direito material, durante o curso do processo abordado, demonstra que as tutelas provisórias de urgência, visam a real efetividade no processo judicial.

Sendo assim, buscou-se, pois, por meio deste trabalho, realizar um estudo sobre tais tutelas, de modo a solidar sua real aplicabilidade no processo judicial. Ao desenvolver essa pesquisa, demonstrou-se que o legislador inovou no âmbito dos requisitos autorizadores para sua cessão, que sofreu uma centralização por parte do novo Código de Processo Civil.

Ainda, a Emenda Constitucional 45/2.004 trouxe em seu esboço a garantia de uma razoável duração do processo e meios que garantam a celeridade de sua tramitação, trazendo em seu texto a dignidade da pessoa humana o direito ao devido e célere processo legal.

Nesta feita, a necessidade de conciliar a segurança jurídica, a tutela jurisdicional com a celeridade proveniente da Emenda Constitucional 45/04 faz com que o Estado, através dos juízes, busque garantir a melhor solução sem que um princípio predomine sobre outro, podendo utilizar dos meios legais viáveis para primar pela celeridade.

A razoável duração do processo nada mais é do que técnica, princípio, garantia e direito no Estado Democrático de Direito, positivada na Lei Maior de 1.988 e protegida pelos poderes a ela vinculados, sendo a utilização deste instituto uma nova ferramenta de suma importância, não apenas para as tutelas de urgência, mas no processo de maneira em geral. 
Podemos assim dizer que o Código de Processo Civil, ao tratar do sistema de tutela provisória de urgência, está em plena consonância com a nossa Lei Maior de 1.988, ao modo que, a busca pela eficácia na prestação jurisdicional de toda sociedade e do Estado brasileiro visa assegurar direitos e garantias de seus tutelados.

Logo, as tutelas de urgência cautelares e antecipadas estabelecem meios eficientes a realizar uma prestação jurisdicional em tempo razoável, com a finalidade de diminuir as mazelas advindas da demora processual, uma vez que, concilia o tempo do processo com as situações de perigo, partilhando, por consequência o ônus advindo do processo entre os sujeitos processuais.

Ponto importante também abordado foi que, muito embora não se tenha alterado a natureza jurídica das tutelas cautelares e antecipadas, ambas possuem os mesmos pressupostos autorizadores para a sua concessão (fumus boni iures e periculum in mora), o que evidencia que o legislador quis facilitar e desburocratizar o acesso a tais medidas.

Assim, exige que o Juiz realize o juízo da ponderação no caso em concreto, dos princípios da necessidade e da proporcionalidade com o objetivo de justificar sua decisão e desta forma sem prejudicar o devido processo legal chegar a uma tutela jurisdicional mais adequada e com a celeridade garantindo uma segurança jurídica para as partes do litigio.

Para fins desta pesquisa, compreendemos que o atual Código de Processo Civil, ao inovar no sistema processual referente às tutelas provisórias, buscou-se harmonizar com a própria Constituição da República Federativa do Brasil de 1.988. Logo, a nosso ver, as tutelas provisórias de urgência e de evidência constituem-se instrumentos efetivos a fim de realizar uma prestação jurisdicional em tempo razoável, ao menos, relativizando os prejuízos resultantes da demora processual.

\section{REFERÊNCIAS}

BRASIL. Constituição da República Federativa do Brasil, de 05 out. 1988. Diário Oficial da União, Brasília, 05 out. 1988. Disponível em: <http://www.planalto.gov.br/ccivil_03/constituic ao/constituicaocompilado.htm>. Acesso em: 5 mar. 2018.

BRASIL. Código de Processo Civil de 2015, de 16 de março de 2015. Diário Oficial da União.

Disponível em: < http://www.planalto.gov.br/ccivil_03/_ato20152018/2015/lei/113105.htm>. Acesso em: 24 maio 2018.

BRASIL. Supremo Tribunal Federal. Primeira Turma. Agravo Regimental no Agravo de Instrumento ${ }^{\circ}$ 715760-RJ. Rel. Min. Rosa Weber, Brasília, 14 nov 2012. Diário de Justiça da União, Brasília, 27, nov. 2012. Disponível em: <http://www.stj.gov.br>. Acesso em: 26 maio 2018 .

. Tribunal de Justiça do RS. Sétima Câmara Cível. Agravo de Instrumento ${ }^{\circ}$ 70075912246-RS. Rel. Sandra Brisola Medeiros. Julgado em 28 de mar. 2018. Disponível em: <https://tjrs.jusbrasil.com.br/jurisprudencia/561818872/agr avo-de-instrumento-ai-70075912246-rs>. Acesso em: 26 maio 2018.

DAMASCENO PENATI, Rafael Augusto. A efetividade da tutela jurisdicional e as tutelas provisórias. Rev. Científica Eletrônica UNISEB, Ribeirão Preto, v.5, n.5, p.143-152, jan. /jun.2015.

DIDIER, Fredie Jr; BRAGA, Paula Sarno; OLIVEIRA, Rafael Alexandria de. Curso de Direito Processual Civil vl. 1, Salvador - BA: Editora JusPodivm, 2009. 
DINAMARCO, Cândido Rangel. Instituições de Direito Processual Civil. Volume 1. $5^{\mathrm{a}}$ ED.: São Paulo. Editora Malheiros, 2005.

; LOPES, Bruno Vasconcelos Carrilho.

Teoria Geral do novo Processo Civil. São

Paulo: Malheiros, 2016.

GONÇALVES, Marcus Vinicius

Rios. Direito Processual Civil Esquematizado /coordenador Pedro Lenza. -6. ed.- São Paulo: Saraiva, 2016.

MARINONI, Luiz Guilherme; ARENHART, Sérgio Cruz; MITIDIERO, Daniel. Novo Código de Processo Civil comentado. 2. ed. rev., atual. eampl. São Paulo: Revista dos Tribunais, 2016.

. Manual do processo de conhecimento. $4^{\mathrm{a}}$ ed., São Paulo: Revista dos Tribunais, 2009.

MESQUITA, Eduardo Melo de. As tutelas cautelar e Antecipada. São Paulo: Editora Revista dos Tribunais, 2002.

NEVES, Daniel Amorim Assumpção. Manual de direito processual civil - Volume único, 8 . Ed. - Salvador: Ed. JusPodivm, 2016.

SANTOS, Paulo Junior Trindade dos.

Anotações aos artigos 305 a 310. In.

MACEDO, Elaine Harzheim; MIGLIAVACCA, Carolina Moraes (coords). Novo Código de

Processo Civil Anotado. OAB/RS. Porto

Alegre: OAB RS, 2015. P. 248.

THEODORO JR., Humberto. Curso de direito Processual Civil. Vol. II, $41^{a}$ Edição. Rio de Janeiro: Forense, 2007.

. Curso de Direito Processual Civil.

Vol. 1. 57 Edição. Rio de Janeiro: Forense, 2016.

WAMBIER, Teresa Arruda Alvim et al. (coord.). Primeiros comentários ao novo Código de Processo Civil: artigo por artigo. 2. ed. rev., atual. e ampl. São Paulo: Revista dos Tribunais, 2016.
Carlos Henrique Levenhagen

Acadêmico do curso de Direito da Universidade Vale do Rio Verde (UNINCOR/MG).

\footnotetext{
Marcos Victor Levenhagen

Bacharel em Administração pela Faculdade Cenecista de Varginha (FACECA/MG) e acadêmico do curso de Direito da Universidade Vale do Rio Verde (UNINCOR/MG).
}

\section{Olívia da Cruz Campos}

Formada em Habilitação em Docência na Educação Infantil e Anos Iniciais do Ensino Fundamental pela Universidade Presidente Antônio Carlos (UNIPAC/MG), especialista em Segurança do Trabalho pela Universidade Candido Mendes (UCAM/RJ) e Acadêmica do curso de Direito da Universidade Vale do Rio Verde (UNINCOR).

Edson Camara de Drummond Alves Junior
Bacharel em Direito pelas Faculdades Integradas
Vianna Junior (FIVJ/MG), Especialista em Direito
Civil e Processual Civil pela Universidade Candido
Mendes (UCAM/RJ) e MBA Executivo em Direito:
Gestão e Business Law pela Fundação Getulio
Vargas (FGV/RJ). Advogado (OAB/MG 109.987) e
professor de Direito Processual Civil no curso de
Direito da Universidade Vale do Rio Verde
(UNINCOR/MG).

